\title{
Look out Below (and Above)! Challenging Adult Understandings of Displaying Young Children's Artwork
}

\author{
DANIELLE TWIGG \\ School of Education and Professional Studies, \\ Griffith University, Queensland, Australia
}

\begin{abstract}
Children's artwork displays are a distinct and key feature of early childhood classrooms. The artwork produced by young children in the classroom is often linked to the educational program. After the completion of the art projects, early childhood educators face the challenge of displaying the children's artwork. With minimal research available on the 'how to' aspects of displaying children's art, educators rely on traditional methods of display, such as fair and equitable representation. Based on a selection of findings from a doctoral research conducted with children between the ages of four and six, this article offers early childhood educators (and adults, generally) insight into young children's lived experiences of the display of their own visual artwork. Discussed in this article are three key themes that were identified in the doctoral study that offer guidance towards a new method for displaying children's artwork. These include: (1) the practices of making and displaying art cannot be separated; (2) decisions about the display of children's visual artwork are made by adults; and (3) art experiences directly impact the lives of young children. This article asserts that adult sensitivity and acknowledgement of children's rights are essential aspects of the decision-making process associated with displaying children's artwork.
\end{abstract}

\section{Introduction}

Close your eyes for a moment. Imagine it is a beautiful, sunny morning and you are on your way to the local kindergarten. As you get closer, you can hear the joyous sounds of children laughing and playing, as they spill out of the building. You are greeted at the door by a teacher and a few curious children. Once inside, your visual sense is overwhelmed by the bright colours that fill the classroom. You notice that some children are building with blocks, some are dressing up, and others are at the art table wearing smocks while they paint on giant sheets of paper. As an adult, you find it difficult to navigate through the maze of drawings hanging down from clotheslines without bumping into the table of clay figurines. You are amazed at the large amount of art production by such young children in one small space. Your thoughts are interrupted by a young girl who is tugging on your shirt to get your attention. She offers you a drawing that she has created 'just for you' even though you arrived just five minutes ago. You hesitate for a moment and then thank the darling little child for the gift she has bestowed upon you. Your heart feels a surge of warmth as you tell the child the drawing is 'beautiful' and she begins to smile. You notice the clock on the wall and realize it is time for the children to begin their schoolwork. As you depart, you are given a heartwarming farewell by the children and it makes you feel very special.

At various times throughout the day, you recall moments of this brief, but powerful experience. You think to yourself, what is it about artwork in a kindergarten classroom that makes it so inviting? Is there a link between children's art experiences and their artistic ability? Do children 
ever feel disappointed with the art that they create? Are children aware of the opinions of people viewing their artwork? How does the display of children's artwork impact children, if at all? The previous story illustrates the prominence of art in the everyday experiences of young children and some of the challenges early childhood educators face when making decisions about the display of children's visual artwork. Based on key findings from doctoral research into young children's experiences of the display of their own visual artwork (Boone, 2008), this article offers some guidance to teachers (and other adults) who regularly engage in the practice of displaying children's artwork.

\section{Researching the Art Experiences of Young Children}

In recent years, research in early childhood art education has gained attention (Wright, 1991; Bresler, 1992; Piscitelli, 1993; Thompson et al, 1995; Kindler, 1997; Wright, 2003). Although a large proportion of art education research focuses on older children (over the age of eight) and adolescents (Fiske, 1999), numerous studies of young children's art experiences have been published. Research indicates that art fosters cognitive development (Eisner, 1996; Seefeldt, 2002; Gardner, 2004). Early childhood art education studies have focused on drawing as a tool for young children's reflections (Brooks, 2005; Chang, 2005), young children's responses to art in museums (Piscitelli, 2001; Anderson et al, 2002; Weier, 2004), and art education pedagogy in early childhood settings (McArdle, 1999; McArdle \& Piscitelli, 2002) to name a few. However, early childhood educationalists consider aesthetics when displaying children's artwork, but do not readily take into account children's rights and abilities to make decisions as individuals (United Nations, 1991; James $\&$ Christensen, 2000) surrounding the act of artwork display (Boone, 2008). This article examines one aspect of early childhood arts education, and attempts to contribute to the corpus of research in this important area.

\section{Traditional Methods of Displaying Young Children's Artwork}

Notions of the 'child as artist' have been framed by philosophical perspectives of early childhood pedagogy, such as child development theory and the sociology of childhood (James \& Prout, 1997; James et al, 1998; McArdle \& Piscitelli, 2002; Corsaro, 2005). According to McArdle (2001, p. 94), in Australia, for example, classroom displays still commonly feature twenty-five identical Christmas trees on photocopied paper.' Traditionally, children's visual artwork (e.g. paintings, drawings, collages) hangs on walls, bulletin boards and windows in classrooms and hallways (Seefeldt, 2002). Other forms of artwork like sculptures may be featured in showcases or on tables in similar locations around a school. The target audience includes peers, other students, parents, teachers, principals, and other adults - primarily members of the school community (Seefeldt, 2002). Depending on the type of artwork (e.g. thematic culminating activity, holiday art, etc.), it may be displayed in a variety of ways, both formal and informal. If parents have been invited to the school for a special occasion, for instance, artwork from each member of the class would normally be represented in a more formal display (Seefeldt, 2002). Alternatively, drawings created during selfdirected activities by the children may or may not be displayed, based on the teacher's decision.

Art educator and teacher Frances Derham offers practical advice for displaying student artwork:

For the kindergarten or school that wishes to keep a proportion of its children's art for display or for study, I suggest the following - all work be hung on the wall until the end of the week. Then the children are allowed to take an agreed number home; the problem of how to hang all can be solved by either putting thin $2 \frac{1}{2}$ in. nails into a 'pinning' strip of wood on the wall and thrusting six or even eight drawings on each pair of nails - or using big 'bulldog' clips which hang on the wall. $(1961 / 2001$, p. 82)

These suggestions for managing the display of children's artwork in early childhood classrooms focus on the practicalities of teaching. They address issues of display from a program perspective, where the focus is on the current theme or unit of study. Democratic issues of space and fair representation are also noted. Stating that the 'children are allowed to take an agreed number 
home' indicates that the children have some choices regarding their own artwork, but ultimately, it seems that teachers decide how and when children's artwork will be sent home.

\section{The Reggio Emilia Approach}

Documentation of children's work at various stages in the learning process is a hallmark of Reggio Emilia learning centres (Malaguzzi et al, 1998; Burnaford, 2001). Display boards are located around each centre, demonstrating children's learning as participants in projects (Moore, 2006). In Edwards, Gandini \& Forman's (1993) book entitled The Hundred Languages of Children: the Reggio Emilia approach to early childhood education, various forms of documentation, 'validate the children's self-esteem, and more importantly, provide a systematic way for children to revisit their experiences (with attendant thoughts and feelings) and then reconstruct and reinterpret them in a different way' (p. 265). Reggio Emilia centres have specific guidelines for displaying work on documentation boards, so that they are uniform and designed to enhance the existing aesthetic environment (Edwards et al, 1993; Malaguzzi et al, 1998; Burnaford, 2001; Moore, 2006). Adults, including the atelierista (a specialist teacher trained in art education), assemble the documentation boards after selecting the contents from the children's project work (Edwards et al, 1993). With this model of display, negotiation may or may not occur between teacher and student regarding the content of the board (Moore, 2006).

Based on the principles of the documentation style of Reggio Emilia learning centres, Seefeldt (2002, p. 14) considers the display of children's artwork 'a form of communication' between children and adults. Like Lowenfeld \& Brittain (1970), Seefeldt (2002, p. 15) recommends labelling displays to assist parents in recognizing the importance of 'scribbles, random drawings, and the seemingly abstractness of children's paintings.' Also, Seefeldt (2002, p. 15) recommends writing explanations of children's scribbles or symbols to 'inform and reassure parents that their children are learning', suggesting that children's artwork should be valued by adults, as it forms a means of evaluating children's learning. As with the Reggio Emilia approach, the amount of influence children have on the display of their own artwork following Seefeldt's (2002) suggestions is not clear.

\section{Why Challenge Traditional Methods of Displaying Young Children's Artwork?}

Artwork is displayed with an audience in mind. Art-making is a process which results in a product. In light of children's artwork being displayed as a means of communication and documentation of learning (Edwards et al, 1993; Seefeldt, 2002), it is important to consider variations in children's ability (Lowenfeld \& Brittain, 1970). Regardless of how much effort teachers put into equitably representing children's artwork in their classroom, individuals who view children's artwork will judge the merit of one creation over another (Lowenfeld \& Brittain, 1970).

It is important to note that, due to their personal association with their work, artists themselves have admitted that exhibiting their own work can be a traumatic experience, for fear of criticism (Kirchenbaum \& Reis, 1997; Mace, 1997). Derham (1961/2001) discourages art competitions as well as group discussions about children's art. Yet sensitive talk between an adult and child about the child's art, a technique used by art therapists as a way to establish rapport with emotionally disturbed individuals of all ages, enhances the art experience (Derham, 1961/2001; Wilson et al, 1987). This suggests that increased adult sensitivity is important to working with children (Van Manen, 1991), which when applied to the act of displaying young children's artwork may result in a more positive artistic learning experience for young children (Boone, 2008).

\section{Children's Experiences with the Display of Their Own Visual Artwork Revealed}

The purpose of this doctoral research was to investigate young children's experiences of their visual artwork being displayed. As a young student and later as a teacher in an arts-focused school in the USA, I noticed the numerous ways in which children's artwork is displayed in schools. During seven years of teaching, only in one isolated occasion was a student given a choice about where, when and how his own artwork was to be displayed. The phenomenon of display of young 
children's visual artwork seems worthy of a formalised investigation, since it occurs on a regular basis in classrooms (Malaguzzi, et al, 1998; Jalongo, 1999; Seefeldt, 2002).

Van Manen (1991) maintains that human science research should be undertaken in a thoughtful and tactful manner. This research (Boone, 2008) uses phenomenology to describe the lived experiences of children whose visual artwork is displayed. Although phenomenology has been used as a way of researching young children's lived experiences of space (Beekman, 1983), time (Briod, 1989), and loneliness (Kirova-Petrova, 2000), it has not been used in the area under discussion here. Phenomenology is a particularly suitable approach for studying the lives of children because it encourages expressive dialogue between children and adults, sees each child as a unique individual, and encourages renewed engagement with adult assumptions about children and childhood (Beekman, 1983; Van Manen, 1991). Other methodologies would enable a different look at this same phenomenon, such as ethnography, phenomenography, grounded theory or case study. They could not however be applied to the same degree when investigating children's experiences with the display of their own visual artwork.

Phenomenology was not originally developed as a research approach; it was purely a philosophical analytical approach. In the early 1960s, phenomenology came to be recognised as an approach to understanding educational phenomena. The work of Maxine Greene (1973) and Vandenberg (1971) was the first to consider phenomenological insights in education. Phenomenology asks, 'What is the nature of experience?' It allows humans to consider their experiences by connecting with the original experience by using thoughtful awareness of what is taken for granted (Van Manen, 1984). Early childhood educational researchers are interested in learning about children's experiences and critiquing discourses of child development so that this knowledge may inform pedagogy (Mayall, 1994; Gadamer, 1999; Lewis \& Lindsay, 2000; Greig et al, 2007). They are curious about how best to act responsibly and responsively with children in relation to their education and general well-being. By investigating young children's art experiences with the display of visual artwork in early childhood settings, and developing a description of the lived experiences of children, educationalists may become better informed about the impact of various approaches to art display.

Existential phenomenological psychologist Amadeo Giorgi (1985) suggests that by analysing and describing how things come into consciousness, 'phenomena' or lived experiences of individuals, can be revealed. Giorgi (1985) used Merleau-Ponty's (1962) creation of the phenomenological method as a foundation for describing his research approach, by translating the phenomenological perspective into a methodology. Guided by Giorgi's (1985) methodological approach, semi-structured interviews were conducted with the children and constituted the data for this study (Boone et al, 2009). Using Giorgi's (1985) phenomenological approach, the investigator seeks descriptions from others who are willing to share their lived experiences. For example, children's verbal explanations of their experiences with art in school are considered authentic and meaningful descriptions.

Interviews were conducted in three rounds for the duration of 10-15 minutes. A list of questions was generated prior to each interview round to stimulate each participant to discuss their personal experiences with the display of their own visual artwork.

Several steps were taken in the data analysis process following Giorgi's (1985) methodology. First, each interview was transcribed from the original audio recording. Next, each transcript was carefully read several times in order to understand the fullness of the participants' descriptions. Then, key words and phrases were identified within each description. Next, following Giorgi's (1985) methodology, the essential key words and phrases were rewritten in the form of specific descriptions. And, finally, each description was cross-checked against a set of tentative themes which were identified within all of the participant descriptions in order to develop a general description of the phenomenon.

\section{The Research Site}

The research site from which the participants were drawn is located in the USA and is an independent school. This school was selected as the research site for three reasons: first, the researcher has a professional association with the school; second, the school's early childhood 
centre includes male and female students from high to low socio-economic backgrounds; and finally, the school has a strong commitment to the arts. Thirteen participants (eight girls and five boys) between the ages of four to six from four classrooms at the research site participated in the study. The research site has a significant focus on art education both in the early childhood centre, where the study occurred, as well as in the other schools (primary, secondary and tertiary) on its campus.

The major ethical concern in this study was the involvement of young children in the research. Finding a balance between accessing children's perspectives and the risks associated with their participation in research is a challenge (Mayall, 1994; Lewis \& Lindsay, 2000; Danby \& Farrell, 2004; Farrell, 2005). Methods used in researching children's perspectives need to be carefully considered in light of children's rights (Lewis \& Lindsay, 2000), not to mention parental and societal concerns (Farrell, 2005). It is important for children to know their rights and feel comfortable participating in research. Before engaging in interviews for the purposes of this study, children were given the opportunity to withdraw from the interview at any time. Moreover, each child's teacher was consulted prior to the interview, and interviews in which a child appeared uncomfortable for any reason were immediately ceased. Approval to conduct the research was sought from the University Human Research Ethics Committee as well as from the research school, the participants themselves and their parents or guardians. Pseudonyms were used in this study to maintain confidentiality.

\section{Methodology}

This study used phenomenology as the conceptual framework, as well as to provide a methodology for understanding young children's experiences of the display of visual artwork. Unlike critical theory, phenomenology is the study of the lived experience (Husserl, 1970). Thus a phenomenological study was undertaken so as to examine the meaning of visual artwork display experiences for young children. For the purposes of this study, existential phenomenological psychology (Giorgi, 1985) was deemed the most appropriate research approach for this investigation, since it has the potential to reveal children's experiences with the display of their own visual artwork and, in particular, to unravel children's experiences of the display of their own visual artwork in early childhood educational settings.

\section{Data Collection}

There were three main phases in this study: phase one - observation; phase two - introductory interviews; and phase three - semi-structured interviews using document samples (artwork) as prompts. An overview of each of the three phases of the study is now provided.

\section{Phase One: observation}

The best way to enter naturalistically into the life-world of a person is through participation in it, suggests Van Manen (1997). To take such a naturalistic approach, the researcher needs to make the transition into the classroom before starting data collection. A key aim of the observations and interactions in phase one was to establish rapport with the potential pool of children involved in the study (Kirova-Petrova, 2000). Conversations with children about their everyday experiences in school, both in groups and in one-on-one interactions during phase one were used to assist in participant selection.

\section{Phase Two: introductory interviews}

Researching with young children is seen to need special skills. As Beekman (1983) has pointed out: 'As with most human science research, the researcher is required to engage in dialogue with the participants, or in the case of children as participants, engage in dialogue with children' (pp. 36-44). In order to familiarise the children with the interview process, an informal assessment was made during an introductory interview (phase two) of each child's comfort level in conversing with 
adults, and in articulating their level of interest in discussing the display of artwork. During phase two, children were invited to respond to general questions about their everyday school experiences, offering insight into the initial reactions children have to artwork display experiences. Although this information did not constitute data for analysis, it was utilized for the development of the semi-structured interview guiding questions for the final phase of the study.

\section{Phase Three: semi-structured interviews}

According to Polkinghorne (1989), phenomenological interviews typically require enough time to explore the description of experience through a semi-structured conversation. Multiple interview sessions can be used in phenomenological studies to access the lived experiences of participants (Polkinghorne, 1989). Each participant in this study was involved in up to three semi-structured interviews sessions that lasted approximately 15-20 minutes, over the course of a few weeks.

Prior to each interview session, the researcher developed a set of guiding questions. Some of these questions included: 'What is it like to see your artwork in your classroom?' or 'What did you think when you saw your picture on the wall?' or 'How do you feel when other people see your artwork on display?' The questions were worded very carefully; as the language of phenomenological semi-structured interviews should be familiar to the children, and should also lead them to respond on the basis of their own personal experiences. Each interview session focused on different aspects of the experience under investigation, based on the previous set of interviews, in an attempt to get rich description from the participants.

\section{Data Analysis}

Phenomenological research focuses on one source of data to uncover the phenomenon, using semi-structured interviews. Participants are asked to write or speak about their specific experience of a phenomenon; the information they offer is considered authentic. A phenomenological description is only one interpretation of human experience. Other phenomenological descriptions of the same experience may complement or add to the richness of the original description.

For this study, participants were interviewed on three separate occasions, and each interview was treated as a separate lived experience. As stated previously, data analysis followed Giorgi's (1985) four-step approach. As the data analysis process is the subject of another publication (Boone et al, 2009), a brief overview is provided in this article.

As stated previously, the outcome of a phenomenological study is general. As a result of the data analysis process, numerous specific descriptions of children's experiences with the display of their own visual artwork emerged (Boone, 2008). A number of themes considered essential to young children's experiences with the display of their own visual artwork also emerged from the larger study (Boone, 2008). For purposes of this article, three specific descriptions from the participants are used to illustrate the impact traditional methods of art display have on young children. The specific descriptions of the participants' experiences have been rewritten by the investigator and analysed in accordance with Giorgi's (1985) approach to data analysis. The first specific description, from Anna, highlights the impact of teacher's assumptions about displaying; Georgia's specific description demonstrates how children can be disappointed by the artwork they create; and the third specific description from Jackson shows that children are highly cognizant of people's opinions of their artwork. All three of the specific descriptions illustrate young children's desire to make choices about their artwork being displayed.

\section{Anna and the Easel}

Anna loves to make paintings at school. Anna recalls a time when she did not want her art to be displayed in her classroom. When she was four years old, Anna made a painting at the easel. She did not remember what she painted on the easel. Anna finished her painting and her teacher told her it would hang on the wall for a while. Anna told her teacher she did not want it to be hung up in the classroom because she enjoys taking her artwork home right away. Anna's teacher told her she would get the painting back after it was dry and had been displayed. Anna agreed to let her 
teacher display the painting even though she would have preferred to take it home. Anna walked over to the acrylic frame hanging on the wall in her classroom where her painting was displayed. Anna noticed that it was no longer on display. After Anna's teachers take paintings down, they roll and tape them. All of Anna's paintings are sent home in her schoolbag.

\section{Georgia's Blue Snow}

Georgia recalls a time when she did not want her art displayed. She and a friend had made snowman paintings. After taking them out of the drying rack, Georgia and her friend discovered that the white snow on the bottom of the painting had turned blue. Neither Georgia nor her friend wanted their paintings displayed for others to see. When Georgia and her friend's paintings did not come out as they had hoped, the teachers displayed them anyway. Georgia felt mad and wished her teachers had given her a choice in displaying it. Georgia does not recall her teachers ever asking her to make a decision about her artwork being displayed. When Georgia is happy with her art, she does not mind having it displayed. If she makes a mistake, she does not want other people to see it. She asserts teachers should give children the choice sometimes.

\section{Jackson's Mistake-Free Butterfly}

Jackson enjoyed making his paper butterfly sculpture. When looking closely at his butterfly, Jackson noticed the 'I' shape he had made with the decorations on the symmetrical wings. Jackson is quite happy with the finished butterfly. Jackson's peers were also happy with their butterflies because none of them made mistakes. When Jackson or his peers make a mistake in their art, they are disappointed because it means that their art is not going to turn in the way it was planned. Jackson has made mistakes in his art in the past and does not like the way it makes him feel. When Jackson makes a mistake with his art and his teachers display it anyway, he avoids looking it so that he can ignore how it might make him feel, since he knows he is not happy with the final result. Even though Jackson knows his art has a mistake, he does not think other people notice it the same way as he does when they see it on the wall. Jackson asserts that people looking at it would just think it is unique compared to the other works of art surrounding it.

\section{Key Findings}

This study highlights the connections this sample of young children have to their artwork and underscores the personal investment they make throughout the entire art experience, that is, from the initial idea to the finished piece on display and every step in between. The aforementioned descriptions, taken from three of the 13 children interviewed for this study, indicate that making art is a pleasurable experience for young children, as it fosters positive feelings (i.e. happiness, pride) in them about the art they have created. Children enjoy the social aspects of making art both at home and at school, as they like engaging with others, including peers, siblings, and adults. The experience of creating art allows young children to build friendships, as it provides a common experience and point of discussion.

As evidenced by the selection of specific descriptions, throughout the art creation process, children are engaged in thoughtful reflection. The creation process begins with the conception of an idea (from the child's imagination or as the result of teacher instruction), followed by careful selection of materials (planning and making decisions based on their own feelings), discussion with peers (general socializing or discussion specific to the art itself, as well as observations such as colour bleeding etc.), and finally the completion of the piece of artwork (when it is finished and they indicate a level of satisfaction with their creation). Children's emotional investment in the creation process is also evident in the fact that they revisit and add detail to artwork they created in the past.

Overall, children enjoy seeing art displayed in a variety of ways (e.g. on walls, in showcases, inside classrooms) by their teachers. Children make assumptions about the art of their peers, asserting that it shows them that the child-artist is a nice person who likes making art and going to school. Art displays include the work of various children and help to make the school environment 
colourful and attractive. Children enjoy seeing the art of adults displayed at school. Young children enjoy art displays because they remind them of previous school experiences. Art displays can inspire young children to create different kinds of art on their own.

As stated in the children's specific descriptions, there is no doubt that the art experiences of young children are shaped by art-related procedures developed by classroom teachers. Children are aware of the procedures for creating, displaying and/or taking home school art projects. When making school art projects, teachers give step-by-step instructions to children. Teachers expect children to work hard on school art projects and show their ability to follow directions. School art projects are associated with units of study and must be completed within a designated period of time in school. When making art at school, a variety of supplies are on offer for children to use. Adults (teachers, parent volunteers) sometimes assist children with aspects of school art projects. Children's names are always noted on their artwork for purposes of identification. Children are allowed to make their own art if there is extra time after the project is complete. After art projects are complete, teachers display the art for long periods (weeks, months) in special ways to make the school look more attractive. Art that is displayed outside a classroom is made by the children within that classroom, and can also be found throughout the school. The art of older children is more likely to be seen within their own classroom, as it often is linked to a major project or unit of study. Children understand that school art is displayed differently from art in an art museum or gallery. Children are aware that teachers will not offer them options for displaying their school art projects.

The children in this study noted that when they are dissatisfied with art in its final form (due to colours bleeding, challenges in drawing), they are disappointed. As a result, children do not enjoy sharing this artwork with others - through display or any other means of sharing. Some 'mistakes' can be easily fixed (erasing a pencil drawing) prior to completion, but if children are unable to correct the mistakes, they prefer to start over from the beginning. Young children may dislike a piece of art for various reasons and feel others will judge them negatively based on its appearance. Children may be concerned that viewers will think their artwork was produced by a younger child or by another child with limited artistic ability.

Children participating in the study mentioned in their descriptions that they often make comments to one another about their artwork. Young children assert that when people view their artwork, they remember the art they created in the past and recognize individual improvement or mistakes in the art. When children are dissatisfied with art, they do not want it to be displayed because viewers might perceive them as artistically inadequate. Children see themselves as artists and it is important to them that others believe they created the art without assistance from anyone else. Viewers of children's artwork are able to identify the artist by name, ability and characteristics of the art itself. The age and grade level of children is also identifiable, based on the school art project (i.e. projects associated with specific ages of students in specific grades). Children tend to be proud of the artwork they create and are happy for others to see it because children's art makes viewers feel happy.

The children in this study commented on the process of disposing of 'old' art to make room for 'new' art. Art is kept in a special place at home, often in the child's bedroom desk or drawers. Children prefer to take art home once it is complete at school, or else only have it on display for short periods of time. When children request that their art is not displayed, teachers display their art anyway. Often teachers do not offer children the opportunity to make decisions about their artwork being displayed at school. If children are dissatisfied with their art for any reason, they prefer not to share it. Young children will not look at art displayed that they are dissatisfied with for any reason. Children like making decisions about the display of their own artwork both at school (taking it home immediately after completion, for example) and at home (prominent visibility on refrigerator door, for example) because they have a strong sense of ownership of their artwork.

\section{Challenging Adult Understandings of Displaying Children's Artwork}

Phenomenological research has a strong moral dimension, as it not only uncovers aspects of human experience (Van Manen, 1991, 1997; Ehrich, 1999), but also asks us to be attentive and thoughtful in our responsiveness to others (Van Manen, 1984). This study has revealed that the 
artistic lives of children are strongly influenced by adults. The children who participated in this study relayed numerous experiences of their interactions with adults during the creation and display phases of the artistic process. Children commented on the ways in which their teachers, parents and carers influenced the making and display of art, both at home and at school.

Upon considering the children's experiences of the display of their own visual artwork, it is important to consider the locations in which art is displayed. Many of the children interviewed for this study asserted their awareness of the location of art displays in their own school. For example, in the early childhood centre of the research site, art was displayed on the walls outside each classroom. Art was also displayed, in smaller amounts, on bulletin boards in the classrooms. For older children at the same school, little art was displayed in the hallway due to space limitations. The library had 'showcases' for 'special projects' that teachers wanted to feature. Decisions about the locations and procedures for display need to be considered with care by schools, as this study points out that these decisions have a large impact on the artistic lives of children.

Teachers at all stages of their careers may benefit from additional training in relation to the arts. Core curriculum pedagogical methods are essential to teacher professional development, and this includes pedagogical methods regarding art education. As Jalongo (1999) asserts, teachers who are not confident with their own artistic ability will negatively influence the art of their own students. By simply including art education as part of pre-service training and ongoing professional development, teachers will be given the opportunity to develop basic skills and reflect critically on their own practice to assist themselves in managing artistic learning at school (Miller et al, 2008). The implication for practice is that teachers should be provided with up-to-date research on how best to acknowledge and respect children's emotional investment in their own visual artwork. Adult sensitivity to the child as artist is of critical importance, since a single act of uncensored criticism may have a long-term effect on an individual's concept of his or her own artistic ability (Kirchenbaum \& Reis, 1997; Mace, 1997; Jalongo, 1999; Derham, 2001; Seefeldt, 2002).

\section{Learning from Young Children's Art Experiences}

Three key themes emerged from this study: (1) the practices of making and displaying art cannot be separated; (2) decisions about the display of children's visual artwork are made by adults; and (3) art experiences directly impact the lives of young children. These themes offer some guidance to teachers (and other adults) who regularly engage in the practice of displaying children's artwork. An overview of each of these themes is now provided.

\section{Making and Displaying Art are Equally Important Aspects of the Creation Process}

The practice of displaying children's artwork must acknowledge both the child as artist and the creation itself, as opposed to simply performing a procedural function (e.g. automatically putting all artwork on display in order to represent all students equally, ignoring an individual child's request to opt out of a particular display). Therefore, the data revealed, on both a practical and a theoretical level, that the assumption that the practices of making and displaying art are separate, is incorrect. Instead, display should be treated as one, equally significant aspect of the entire creation process.

\section{Decisions about the Display of Children's Artwork Should Be Made in Consultation with the Child-Artist}

Even when children in this study vocalized their desire not to participate in the children's art display, adults neglected to accept their requests. The research findings indicated that a lack of consideration on the part of adults to allow children to make decisions about the display of their own visual artwork was the norm. The assumption that all children like all of their artwork displayed all of the time is false. Adults (including teachers, parents, researchers, carers and others) must begin to acknowledge children's rights in relation to the child as artist. The simple act of discussing the artwork and the proposed method of display with every child is a very powerful, yet subtle way to advocate for children's rights in relation to their own visual artwork. 


\section{Art Experiences Directly Impact the Lives of Young Children}

The argument that art experiences in school significantly impact young children (Kim et al, 2001; Edwards, 2006) was confirmed by the findings of this study. In addition, art experiences in the home received an equal acknowledgment of significance by the study participants. Children, unlike adults, did not appear to categorise art experiences in the same way as adults (Boone, 2007). The art they create can serve many purposes. For example, a piece of school art may be taken home and given to a parent as a gift. Or art that is created in the home may be kept in a private place, as it was never intended to be shared with others but was made for the pure pleasure of the activity itself. The findings indicated that children recall past art experiences in great detail. These memories of past art experiences are easily recalled by children when they are presented with a piece of artwork they created in the past. Revisiting a piece of art made long ago can stir up an array of emotions in the child-artist, ranging from laughter to sadness and anything in between. For young children, art has great meaning. The artwork of a child is an extension of him or her as a human being. At times, it can demonstrate a child's self-understanding or relationship to others, document new learning, or simply be an expression of the joy of making art! The research findings indicated that adults underestimate the significance of art experiences and the direct impact they have on young children.

\section{Conclusion}

This article began with a visualization of the sights and sounds of a traditional kindergarten classroom. This visualization serves to remind us of the steady creative hum and vibrant colourful pieces of art that saturate many early childhood classrooms. In essence, displays of children's artwork define the kindergarten classroom and shape the work of the children within it. The study on which this article is based provided insight into children's artistic experiences and challenges traditional views of display. It is important to acknowledge that this investigation of young children's experiences of their visual artwork being displayed occurred in a well-resourced, artsfocused school setting. Therefore, it is equally important to consider implications for practice in contexts where there is not such a wealth of resources or strong commitment to the arts. It poses the question, if this problem occurred in this school setting, to what extent is this occurring in other schools?

Although the young child's lived experience with the display of their own visual artwork is merely one aspect of the artistic lives of children, this article asserts that all art experiences shape individuals' views of themselves. By understanding the children's views which were expressed in this study, teachers (and other adults) might be able to add to their insights into the purpose and impact of displaying children's artwork.

\section{Acknowledgement}

I would like to thank Associate Professor Lisa Catherine Ehrich for her invaluable contribution to the development of this article.

\section{References}

Anderson, D., Piscitelli, B., Weier, K., Everett, M. \& Tayler, C. (2002) Children’s Museum Experiences: identifying powerful mediators of learning, Curator, 45(3), 213-231. http: / / dx.doi.org/10.1111/j.2151-6952.2002.tb00057.x

Beekman, T. (1983) Human Science as a Dialogue with Children, Phenomenology + Pedagogy, 1(1).

Boone, D.J. (2007) A Picasso or a Pre-schooler? Ways of seeing the 'child as artist'. Paper presented at the 2007 Philosophy of Education Society of Australasia (PESA) Conference: Creativity, Enterprise and Policy - new directions in education. Wellington, New Zealand.

Boone, D.J. (2008) Young Children’s Experience of Visual Displays of their Artwork, Australian Art Education, $31(22), 22-45$.

Boone, D.J., Ehrich, L.C. \& Lidstone, J. (2009) Researching with and for Young Children: congruence and authenticity in methodology, Encyclopaedia, 8(25), 45-62. 
Bresler, L. (1992) Visual Arts in Primary Grades: a portrait and analysis, Early Childhood Research Quarterly, 7, 397-414. http: / / dx.doi.org/10.1016/0885-2006(92)90029-X

Briod, M. (1989) A Phenomenological Approach to Child Development, in R.S. Valle \& S. Halling (Eds) Existential-Phenomenological Perspectives in Psychology: exploring the breadth of human experience, pp. 115-126. New York: Plenum Press.

Brooks, M. (2005) Drawing as a Unique Mental Development Tool for Young Children: interpersonal and intrapersonal dialogues, Contemporary Issues in Early Childhood, 6(1), 80-91. http: / / dx.doi.org/10.2304/ ciec.2005.6.1.11

Burnaford, G.E. (2001) Renaissance in the Classroom: arts integration and meaningful learning. Mahwah, NJ, Lawrence Erlbaum.

Chang, N. (2005) Children's Drawings: science inquiry and beyond, Contemporary Issues in Early Childhood, 6(1), 104-106. http: / / dx.doi.org/10.2304/ ciec.2005.6.1.3

Corsaro, W.A. (2005) The Sociology of Childhood, 2nd edn. Thousand Oaks, CA: Forge Press.

Danby, S. \& Farrell, A. (2004) Accounting for Young Children's Competence in Educational Research: new perspectives on research ethics, Australian Educational Researcher, 31(3), 38-50.

Derham, F. (1961/2001) Art for the Child under Seven. Watson, ACT: Australian Early Childhood Association.

Edwards, C., Gandini, L. \& Forman, G.E. (1993) The Hundred Languages of Children: the Reggio Emilia approach to early childhood education. Norwood, NJ: Ablex.

Edwards, L.C. (2006) The Creative Arts: a process approach for teachers and children, 4th edn. Upper Saddle River, NJ: Pearson/Merrill/Prentice Hall.

Ehrich, L.C. (1999) Untangling the Threads and Coils of the Web of Phenomenology, Education Research and Perspectives, 26(2), 19-44.

Eisner, E.W. (1996) Cognition and Curriculum Reconsidered, 2nd edn. London: Paul Chapman.

Farrell, A. (Ed.) (2005) Ethical Research with Children. Maidenhead and New York: Open University Press.

Fiske, E.B. (1999) Champions of Change: the impact of the arts on learning, Washington, DC: Arts Education Partnership. President's Committee on the Arts and the Humanities, John D. \& Catherine T. MacArthur Foundation.

Gadamer, H.G. (1999) Hermeneutics, Religion, and Ethics. New Haven: Yale University Press.

Gardner, H. (2004) Frames of Mind: the theory of multiple intelligences, 20th Anniversary edn. New York: Basic Books.

Giorgi, A. (1985) Sketch of a Psychological Phenomenological Method, in A. Giorgi (Ed.) Phenomenology and Psychological Research, pp. 8-22. Pittsburgh, PA: Duquesne University Press.

Greene, M. (1973) Teacher as Stranger: educational philosophy for the modern age. Belmont, CA: Wadsworth.

Greig, A., Taylor, J. \& MacKay, T. (2007) Doing Research with Children, 2nd edn. Los Angeles and London: Sage.

Husserl, E. (1970) The Crisis of European Sciences and Transcendental Phenomenology: an introduction to phenomenological philosophy. Evanston, IN: Northwestern University Press.

Jalongo, M.R. (1999) How We Respond to the Artistry of Children: ten barriers to overcome, Early Childhood Education Journal, 26(4), 205-208. http:/ / dx.doi.org/10.1023 / A:1022922504178

James, A. \& Christensen, P.M. (2000) Research with Children: perspectives and practices. New York: Falmer Press.

James, A., Jenks, C. \& Prout, A. (1998) Theorizing Childhood. Cambridge: Polity Press in association with Blackwell.

James, A. \& Prout, A. (1997) Constructing and Reconstructing Childhood: contemporary issues in the sociological study of childhood, 2nd edn. London: Falmer Press.

Kim, H., Park, E. \& Lee, J. (2001) 'All Done! Take it Home' Then into a Trashcan?: displaying and using children's art projects, Early Childhood Education Journal, 29(1), 41-50. http: / / dx.doi.org/10.1023/ A:1011308906808

Kindler, A.M. (1997) Child Development in Art. Reston, VA: National Art Education Association.

Kirchenbaum, R.J. \& Reis, S.M. (1997) Conflicts in Creativity: talented female artists, Creativity Research Journal, 10(2\&3), 251-263. http:/ / dx.doi.org/10.1080/10400419.1997.9651224

Kirova-Petrova, A. (2000) Researching Young Children's Lived Experiences of Loneliness: pedagogical implications for linguistically diverse students, Alberta Journal of Educational Research, 46(2), 99-116. 
Lewis, A. \& Lindsay, G. (2000) Researching Children's Perspectives. Buckingham \& Philadelphia, PA: Open University Press.

Lowenfeld, V. \& Brittain, W.L. (1970) Creative and Mental Growth. New York: Macmillan.

Mace, M. (1997) Toward an Understanding of Creativity through a Qualitative Analysis of Contemporary Art Making, Creativity Research Journal, 10(2\&3), 265-278. http: / dx.doi.org/10.1080/10400419.1997.9651225

Malaguzzi, L., Zini, M., Ceppi, G. \& Reggio Children (1998) Children, Spaces, Relations: metaproject for an environment for young children. Reggio Emilia: Reggio Children.

Mayall, B. (1994) Children's Childhoods: observed and experienced. London: Falmer Press.

McArdle, F. (1999) Art and Young Children: doing it 'properly', Contemporary Issues in Early Childhood, 1(1), 101-104. http:/ / dx.doi.org/10.2304/ ciec.2000.1.1.2

McArdle, F. (2001) Art in Early Childhood: the discourse of 'proper' teaching. PhD thesis. Centre for Applied Studies in Early Childhood, Queensland University of Technology.

McArdle, F. \& Piscitelli, B. (2002) Early Childhood Art Education: a palimpsest, Australian Art Education, 25(1), 11-15.

Merleau-Ponty, M. (1962) Phenomenology of Perception. London: Routledge \& Kegan Paul.

Miller, M.G., Nicholas, E.L. \& Lambeth, M.L. (2008) Pre-service Teachers' Critical Reflections on Arts and Education Discourse: reconstructions of experiences, Contemporary Issues in Early Childhood, 9(4), 354-364. http:/ / dx.doi.org/10.2304/ ciec.2008.9.4.354

Moore, K.B. (2006) How to Create a School Art Show, Early Childhood Today, 20(5), 8-9.

Piscitelli, B. (1993) Children's Artistic Lives: the gap between rhetoric and reality. Paper presented at the Issues in Australian Childhood Conference, Brisbane, Queensland, Australia.

Piscitelli, B. (2001) Young Children's Interactive Experiences in Museums: engaged, embodied and empowered learners, Curator, 44(3), 224-229. http:/ / dx.doi.org/10.1111/j.2151-6952.2001.tb01162.x

Polkinghorne, D.E. (1989) Phenomenological Research Methods, in R.S. Valle \& S. Halling (Eds), ExistentialPhenomenological Perspectives in Psychology: exploring the breadth of human experience, pp. 41-59. New York: Plenum Press.

Seefeldt, C. (2002) Creating Rooms of Wonder: valuing and displaying children's work to enhance the learning process. Beltsville, MD: Gryphon House.

Thompson, K.B., Loftus, D.S. \& Bullock, K. (1995) Art Connections: integrating art throughout the curriculum. Glenview, IL: Good Year Books.

United Nations (1991) Convention on the Rights of the Child. New York: United Nations.

Vandenberg, D. (1971) Being and Education: an essay in existential phenomenology. Englewood Cliffs, NJ: Prentice-Hall.

Van Manen, M. (1984) 'Doing' Phenomenological Research and Writing: an introduction. Edmonton, AB: University of Alberta Department of Secondary Education.

Van Manen, M. (1991) The Tact of Teaching: the meaning of pedagogical thoughtfulness. Albany, NY: State University of New York Press.

Van Manen, M. (1997) Researching Lived Experience: human science for an action sensitive pedagogy, 2nd edn. London, ON: Althouse Press.

Weier, K. (2004) Empowering Young Children in Art Museums: letting them take the lead, Contemporary Issues in Early Childhood, 5(1), 106-116. http: / / dx.doi.org/10.2304/ciec.2004.5.1.2

Wilson, B., Wilson, M. \& Hurwitz, A. (1987) Teaching Drawing from Art. Worcester, MA: Davis Publications.

Wright, S. (1991) The Arts in Early Childhood, Brookvale, NSW: Prentice Hall.

Wright, S. (2003) The Arts, Young Children, and Learning. Boston, MA: Pearson Education.

DANIELLE TWIGG is a lecturer in the School of Education and Professional Studies at Griffith University in Queensland, Australia. Her research interests are eclectic and include early childhood education, art education, qualitative research methodologies including phenomenology, student well-being, and professional learning for educators. Correspondence: Dr Danielle Twigg, Griffith University, 176 Messines Ridge Road, Mount Gravatt, Queensland 4122, Australia (d.twigg@griffith.edu.au). 